\title{
Peningkatan Pengendalian Diri melalui Layanan Konseling Kelompok Pendekatan Teknik PMRT (Progreesive Muscle Relaxation Training) terhadap Peserta Didik Kelas X MIPA 3 SMA Negeri 2 Brebes Semester Gasal Tahun Pelajaran 2018/2019
}

\author{
Husni Mubarok \\ Guru Bimbingan dan Konseling
}

SMA Negeri 2 Brebes

Guru SMA Negeri 2 Brebes

\begin{abstract}
Abstrak
Ketidakmampuan peserta didik melakukan pengendalian diri tampak pada munculnya perasaan resah terkait kondisi kehidupan ekonomi yang dialami, gaya hidup yang tidak seimbang dengan kondisi diri, sikap keras kepala, pornografi, pelanggaran kedisiplinan secara terbuka, daya konsentrasi rendah, penurunan prestasi belajar, ambisi berlebihan, dan sikap adiktif. Kondisi ini memerlukan bimbingan secara sungguh-sungguh agar peserta didik memiliki kemampuan melakukan pengendalian diri kearah tindakan yang lebih bermanfaat. Penelitian ini merupakan penelitian tindakan bimbingan dan konseling (PTBK), yaitu peningkatan pengendalian diri melalui layanan konseling kelompok pendekatan teknik PMRT (progreesive muscle relaxation training) terhadap peserta didik. Hasil penelitian menunjukan terjadinya peningkatan pengendalian diri pada siklus 1, namun terjadi penurunan pada siklus 2 dan 3. Berdasarkan indikator kinerja, penelitian ini menunjukan keberhasilan berdasarkan rerata secara umum dan per indikator.
\end{abstract}

Kata kunci: Pengendalian Diri, Konseling Kelompok

\begin{abstract}
The inability of students to perform self-control appears in the emergence of feelings of anxiety related to the conditions of economic life experienced, lifestyles that are not balanced with self-conditions, stubborn attitudes, pornography, violations of discipline openly, low concentration power, decreased learning achievement, excessive ambition, and addictive attitude. This condition requires serious guidance so that students have the ability to exercise self-control towards more useful actions. This research is a guidance and counseling action research (PTBK), which is increasing self-control through group counseling service approach to PMRT (progreesive muscle relaxation training) techniques for students. The results showed an increase in self-control in cycle 1 , but there was a decrease in cycles 2 and 3 . Based on performance indicators, this study showed success based on average and per indicator.
\end{abstract}

Keywords: Self-Control, Group Counseling 


\section{PENDAHULUAN}

Pengendalian diri (self control) merupakan kemampuan individu dalam mengendalikan perilakunya untuk mencapai tujuan tertentu. Individu yang memiliki pengendalian diri yang baik ditandai dengan memahami benar konsekuensi akibat tindakan yang akan dilakukan, atau dengan kata lain bahwa pengendalian diri yang tidak baik akan bersikap gegabah sehingga dapat merugikan diri sendiri. Hal ini dinyatakan oleh Lazarus (dalam Hermanto, 2009:4) bahwa pengendalian diri menggambarkan keputusan individu melalui pertimbangan kognitifnya untuk menyatakan perilaku yang telah disusun untuk meningkatkan hasil dan tujuan tertentu sesuai kehendaknya. Sisi lain, Hurlock, 1994 (dalam Ghufron, 2011:23) kendali diri lebih banyak berkaitan dengan bagaimana individu mengendalikan emosi serta dorongan-dorongan dalam dirinya. Dengan kata lain semakin baik individu dalam mengelola gejolak emosionalnya semakin baik kemampuan mereka dalam mengendalikan dirinya. Ronen (1993) (dalam Safaria, 2004:110) menambahkan ada dua langkah penting dalam perkembangan keterampilan pengendalian diri pada anak, pertama kendali orang dewasa terhadap anak dan yang kedua keterampilan verbal pada anak yang akan mendorong anak untuk mengendalikan perilakunya sendiri.

Perilaku peserta didik berdasarkan hasil pengamatan awal menunjukan kecenderungan peserta didik, seperti (1) munculnya keresahan hidup yang dialami peserta didik semakin meningkat akibat kondisi tuntutan ekonomi keluarga yang tidak terpenuhi, masuknya gaya hidup yang tidak seimbang dengan kondisi diri, kekerasan, pornografi, dan pornoaksi (5 atau 33,33\%); (2) kecenderungan terjadinya pelanggaran kedisiplinan secara terbuka oleh peserta didik, khususnya di sekolah dimulai kehadiran yang diterlambat, proses belajar yang cenderung tidak konsentrasi, penurunan prestasi belajar, dan perasaan tertekan terkait penerapan tata tertib sekolah (7 atau 46,66\%); (3) adanya ambisi baru yang berlebihan untuk memaksakan kehendaknya dalam memenuhi kebutuhan (2 atau 13,33\%); dan (4) lari dari masalah ketika peserta didik dihadapkan dengan masalah yang multikrisis sehingga mengambil jalan pintas yang bersifat sementara dan adiktif, seperti mencuri, meminta secara paksa, seks bebas, dan konsumsi obat-obatan secara berlebihan (1 atau 6,66\%).

Fenomena perilaku peserta didik di atas, perlu dilakukan penanganan secara sungguh-sungguh agar peserta didik mampu membawa dirinya kearah tindakan yang memberikan manfaat dan keuntungan secara positif bagi diri dan orang lain. Peserta didik perlu dibimbing agar mampu berjuang menghadapi godaan dan ancaman yang dapat menghancurkan dirinya sehingga peserta didik tetap eksis dan dapat menyesuaikan dirinya dengan tuntutan zaman. Dalam pandangan Nurihsan (2012:68) para pelajar perlu dibekali dengan berbagai kompetensi kepemimpinannya yang berupa strategi pengendalian diri. Lebih lanjut dijelaskan bahwa pengendalian diri akan membekali pelajar dalam menghadapi berbagai godaan yang akan menghancurkan dirinya dan masyarakatnya. Pengendalian diri sebagai kompetensi psikis dapat memberikan kontribusi akan kemampuan peserta didik mengatasi kelemahan-kelemahan yang ada pada dirinya dan akan mampu mengembangkan potensi-potensi yang ada pada dirinya secara optimal.

Selanjutnya, penerapan konseling kelompok pendekatan teknik PMRT (Progreesive Muscle Relaxation Training) merupakan bentuk usaha meningkatkan pengendalian diri peserta didik. Hakekatnya, konseling ini dilaksanakan melalui perpaduan latihan relaksasi otot sebagai teknik yang dikembangkan Jacobson dalam dunia konseling sebagai upaya mengurangi ketegangan individu terkait aktivitas mental sehingga terjadi keluhan-keluhan fisik dan psikologis (Harris, 2003, dalam Erford, 2016: 164-171). Sisi lain, pengendalian diri sebagai objek penelitian telah dilakukan berbagai pendekatan untuk pengembangannya, terutama melalui konseling kelompok dan teknik relaksasi (Fadillah, 2013): Handayani (2017) dan Safitri (2018).

\section{METODE}

Penelitian ini merupakan penelitian tindakan (action research) yang dilakukan melalui prosedur siklus dan penilaian dilakukan secara kolaboratif. Proses keberhasilan penelitian menekankan dua aspek, yaitu aspek pemahaman dan pengembangan. Sumber data hasil penilaian kolaborator, 
pengamatan, penilaian skala pengendalian diri dan refleksi. Adapun teknik dan alat pengumpulan data, yaitu pedoman observasi dan skala skala pengendalian diri.

Analisis data dilakukan hasil observasi dilakukan deskriptif komparatif antara kondisi awal dengan siklus 1 , kondisi siklus 1 dengan siklus 2, dan kondisi siklus 2 dengan siklus 3 . Penilaian skala skala pengendalian diri digunakan deskripsi persentase dengan menetapkan skor maksimal, skor minimal, rentang skor, rentang jenjang (sangat tinggi, tinggi, sedang, dan rendah), dan interval kelas (Sudjana, 1996:47;Sugiyono, 2006:106-107).

Adapun indikator kinerja penelitian, yaitu pengendalian diri peserta didik dinyatakan telah meningkat apabila apabila penghitungan rata-rata pengendalian diri secara umum menunjukan 76,4 poin atau $63,7 \%$ dan per indikator menunjukan 12,7 atau $63,5 \%$. Pencapaian indikator kinerja penelitian menunjukan bahwa tindakan konseling karir pendekatan PMRT efektif meningkatkan pengendalian diri peserta didik kelas X MIPA 3 SMA Negeri 2 Brebes tahun pelajaran 2018/2019. Untuk prosedur penelitian pada setiap proses dan akhir kegiatan per-siklus dilakukan penilaian dan refleksi sebagai bahan pertimbangan menentukan langkah-langkah yang harus dilakukan untuk siklus selanjutnya, sehingga dalam setiap siklus terdapat empat rancangan utama, meliputi: (1) perencanaan (planning); (2) pelaksanaan tindakan (action); (3) pengamatan (observation); dan (4) refleksi (reflection).

\section{HASIL}

Kondisi awal pengendalian diri peserta didik berdasarkan penilaian skala pengendalian diri berada dalam kategori rendah. Meskipun telah dilakukan layanan bimbingan dan konseling dalam bentuk layanan konseling kelompok, namun tidak efek yang signifikan pasca layanan terkait perkembangan pengendalian diri peserta didik. beberapa peserta didik menunjukan kecenderungan tidak mampu melakukan pengendalian diri, hal ini ditunjukan dengan ketidaktercapaian 3 indikator dari pengendalian diri. Adapun peserta didik yang cenderung memiliki pengendalian diri yang rendah, berjumlah 15 peserta didik.

Sisi lain, kondisi awal pengendalian diri peserta didik berdasarkan penilaian skala pengendalian diri (pre tes) (pada saat pemberian layanan juga memberikan informasi bahwa beberapa peserta didik memiliki tingkat pengendalian diri yang rendah. Kondisi pengendalian diri peserta didik dapat disimpukan bahwa terdapat 3 atau $8,3 \%$ peserta didik memiliki tingkat pengendalian diri yang sangat tinggi (ST), terdapat 17 atau $47 \%$ peserta didik memiliki tingkat pengendalian diri yang tinggi (T), terdapat 13 atau $36 \%$ peserta didik memiliki tingkat pengendalian diri yang sedang (S), dan tedapat 2 atau 5,5\% peserta didik memiliki tingkat pengendalian diri yang rendah (R).

Siklus pertama dari hasil penilaian skala pengendalian diri peserta didik dalam kondisi yang belum dikatakan memiliki perkembangan peningkatan pengendalian diri yang diharapkan. Adapun hasil perkembangannya menunjukan 1 atau 6,6\% kategori sangat tinggi, 4 atau 26,66\% kategori tinggi, dan 9 atau $60 \%$ kategori sedang, segi perkembangan indikator pengendalian diri peserta didik juga menggambarkan kondisi hasil siklus I menunjukan, aspek kontrol perilaku menunjukan 1 atau 6,6\% kategori sangat tinggi, 4 atau 26,66\% kategori tinggi, dan 9 atau $60 \%$ kategori sedang. Indikator kedua, aspek kontrol kognitif menunjukan 3 atau 20\% kategori sangat tinggi, 5 atau $33,33 \%$ kategori tinggi, dan 7 atau 46,66\% kategori rendah. Indikator ketiga, aspek mengontrol keputusan menunjukan 5 atau 33,33\% kategori tinggi, 8 atau 53,33\% kategori sedang, dan 1 atau $6,6 \%$ kategori rendah. Ketiga indikator pengendalian diri pasca layanan di siklus 1 bila ditelaah secara mendalam, maka perkembangan pada setiap indikator belum menunjukan peningkatan yang signifikan. Artinya, sasaran pada setiap perkembangan indikator pengendalian belum memiliki efek yang nyata atau siginifikan secara merata dari hasil layanan konseling karier pendekatan PMRT. Hasil penilaian segera (laiseg) menunjukan perkembangan yang lebih baik dan memiliki perasaan yang lebih cenderung pada orientasi perubahan terkait upaya menata dan perbaikan perilakuperilaku yang kurang atau dianggap tidak memiliki pengendalian diri.

Siklus kedua, hasil penilaian pengendalian diri peserta didik pasca layanan disiklus kedua menunjukan 7 atau 46,66\% kategori sedang, 7 atau 46,66 \% kategori tinggi, dan 1 atau 6,6\% kategori sangat tinggi. Penilaian ini memberikan gambaran kondisi pengendalian diri peserta didik yang belum memiliki perkembangan yang merata dan pada level tinggi. Sedangkan penilaian 
pengendalian diri berdasarkan indikator pengendalian diri pada aspek kontrol perilaku menunjukan 1 atau 6,6\% kategori sangat tinggi, 4 atau 26,66\% kategori tinggi, dan 9 atau $60 \%$ kategori sedang. Aspek kontrol kognitif menunjukan 3 atau 20\% kategori sangat tinggi, 5 atau 33,33\% kategori tinggi, dan 7 atau 46,66\% kategori rendah. Sedangkan, aspek mengontrol keputusan menunjukan 5 atau $33,33 \%$ kategori tinggi, 8 atau 53,33\% kategori sedang, dan 1 atau 6,6\% kategori rendah. Adapun perkembangan pengendalian diri peserta didik berdasarkan penilaian segera (laiseg), secara umum menunjukan perkembangan yang lebih baik dan memiliki perasaan yang lebih cenderung pada orientasi perubahan terkait upaya menata dan perbaikan perilaku-perilaku yang kurang atau dianggap tidak memiliki pengendalian diri.

Siklus ketiga, hasil penilaian skala pengendalian diri menunjukan perkembangan yang lebih baik dari siklus kedua, artinya terdapat peningkatan pengendalian diri peserta didik secara umum yang dibuktikan dengan peningkatan persentase jumlah peserta didik dari semula 7 atau 46,66 \% kategori tinggi menjadi 14 atau $93,33 \%$ pada kategori tinggi.

\section{PEMBAHASAN}

Refleksi pada siklus pertama secara umum, proses layanan konseling kelompok pendekatan PMRT berjalan dengan baik meskipun pada awal kegiatan cenderung masih gugup, penentuan materi, dan penerima layanan kurang memberikan apresiasi yang baik. Keadaan ini dapat direduksi melalui pendampingan guru bimbingan dan konseling (peneliti) agar konseli (penerima layanan) tetap dalam keadaan nyaman dan termotivasi dalam mengikuti layanan.

Siklus kedua secara umum, proses layanan layanan konseling kelompok pendekatan PMRT berjalan dengan baik dan tampak terjadi perubahan yang lebih baik dari siklus pertama. Kecenderungan tutor sebaya mantap dan gugup yang tidak nampak, hal ini dipengaruhi oleh penguasaan kelas yang lebih baik dan pengalaman siklus pertama dijadikan perhatian untuk melakukan perubahan pelaksanaan bimbingan teman sebaya yang lebih baik, materi lebih terkuasai, dan penerima layanan memberikan apresiasi yang baik. Keadaan ini merupakan peningkatan keberhasilan layanan konseling kelompok pendekatan PMRT dibandingkan pada siklus pertama, namun pendampingan guru bimbingan dan konseling (peneliti) tetap dilakukan agar konseli (penerima layanan) tetap dalam keadaan nyaman dan termotivasi dalam mengikuti layanan.

Siklus ketiga secara umum, proses layanan layanan konseling kelompok pendekatan PMRT berjalan dengan baik dan tampak terjadi perubahan yang lebih baik dari siklus pertama dan kedua. Kecenderungan tutor sebaya mantap dan gugup yang tidak nampak, hal ini dipengaruhi oleh penguasaan kelas yang lebih baik dan pengalaman siklus pertama dijadikan perhatian untuk melakukan perubahan pelaksanaan layanan konseling kelompok pendekatan PMRT yang lebih baik, materi lebih terkuasai, dan penerima layanan memberikan apresiasi yang baik. Keadaan ini merupakan peningkatan keberhasilan layanan konseling kelompok pendekatan PMRT dibandingkan pada siklus pertama dan kedua, namun pendampingan guru bimbingan dan konseling (peneliti) tetap dilakukan agar konseli (penerima layanan) tetap dalam keadaan nyaman dan termotivasi dalam mengikuti layanan.

Sisi lain, kendala yang dihadapi dalam pelaksanaan layanan dari siklus pertama, kedua, dan ketiga yaitu alokasi jam pelayanan bimbingan dan konseling hanya 45 menit dan terkadang pembelajaran sebelummnya melebihi batas ketentuan, untuk itu dibutuhkan komunikasi yang mendalam terkait kebutuhan jam untuk pelaksanaan layanan.. Meskipun dihadapkan dengan kondisi ini proses layanan dapat berjalan dengan baik, namun untuk mengantisipasi kondisi tersebut dilakukan pengalihan jam layanan di luar kegiatan belajar mengajar (pulang sekolah).

Adapun penilaian pengendalian diri peserta didik berdasarkan hasil analisis skala pengendalian diri dan hasil observasi menunjukan perkembangan yang lebih baik terkait pengendalian diri yang dimiliki peserta didik. Perkembangan pengendalian diri peserta didik dimulai pra siklus menunjukan 9 atau 32,14\% pengendalian diri peserta didik kategori sedang dan 19 atau 67,85 pengendalian diri peserta didik kategori rendah.

Kondisi pengendalian diri peserta didik mulai menunjukan peningkatan dimulai pada siklus I, yaitu terdapat 1 atau 3,57\% kondisi pengendalian diri peserta didik dalam kategori sangat tinggi, 17 atau $60,71 \%$ kondisi pengendalian diri peserta didik dalam kategori tinggi, dan 10 atau 35,71\% 
kondisi pengendalian diri peserta didik dalam kategori sedang. Pada siklus II, perkembangan pengendalian diri menunjukan 18 atau $64,28 \%$ kondisi pengendalian diri peserta didik dalam kategori tinggi dan 10 atau 35,71\% kondisi pengendalian diri peserta didik dalam kategori sedang. Sedangkan hasil akhir pada siklus III berdasarkan penilaian skala pengendalian diri menunjukan 1 atau 3,57\% kondisi pengendalian diri peserta didik dalam kategori sangat tinggi, 16 atau 57,4\% kondisi pengendalian diri peserta didik dalam kategori tinggi dan 12 atau 42, 85\% kondisi pengendalian diri peserta didik dalam kategori sedang.

Rata-rata peningkatan pengendalian diri peserta didik setelah menerima tindakan konseling kelompok pendekatan PMRT pada siklus I diperoleh 22,57 poin atau $18,78 \%$, siklus II diperoleh 3,01 poin atau $2,5 \%$, dan siklus III diperoleh 3,75 poin atau $3,13 \%$. Namun perlu diperjelas, bahwa antara siklus II dan III terjadi penurunan sebesar 0,74 poin atau $0,63 \%$ hal ini terjadi akibat kurangnya perhatian beberapa peserta didik dalam proses layanan, meskipun kondisi tersebut dapat diatasi.

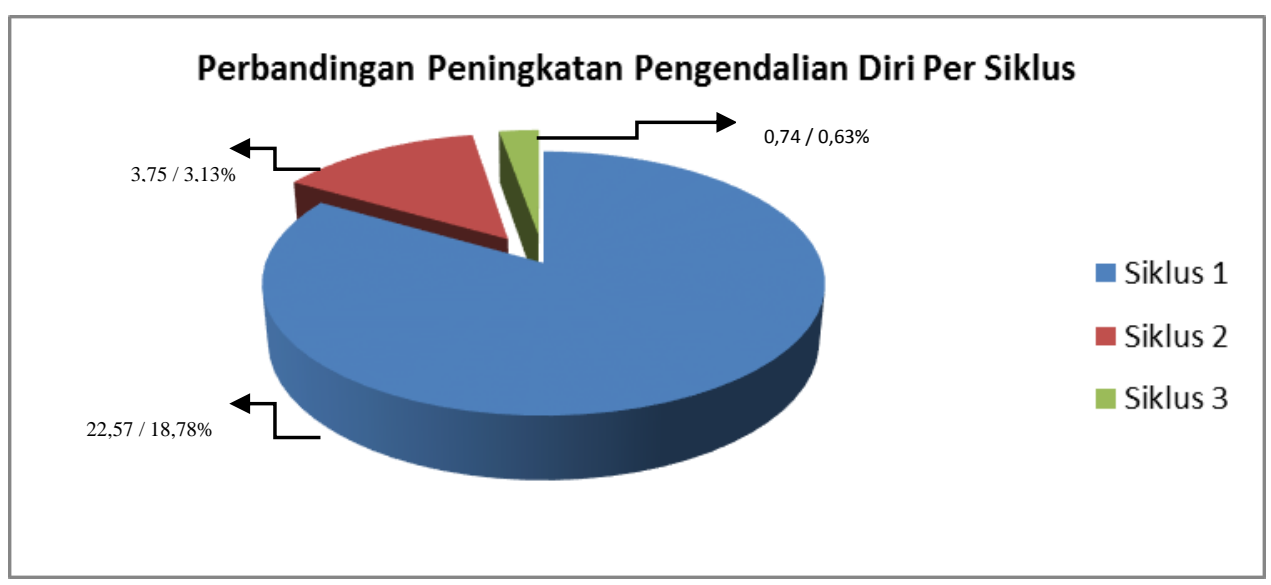

Grafik 1

Perbandingan Peningkatan Pengendalian Diri Per Siklus

Perkembangan pengendalian diri peserta didik aspek kontrol perilaku menunjukan kenaikan pada setiap siklus. Perbandingan antara pra siklus dengan siklus I menunjukan kenaikan 0,4 poin atau $0,1 \%$, siklus I dengan siklus II menunjukan kenaikan 0,5 poin atau $0,5 \%$, dan siklus II dengan siklus III menunjukan kenaikan 0,6 atau $0,6 \%$. Perbandingan ini menunjukan perubahan pengendalian diri peserta didik aspek kontrol perilaku setelah menerima konseling kelompok pendekatan PMRT sehingga dapat dinyatakan bahwa konseling kelompok pendekatan PMRT memiliki kontribusi positif dalam meningkatkan pengendalian diri peserta didik aspek kontrol perilaku.

Perkembangan pengendalian diri peserta didik aspek kontrol kognitif menunjukan kenaikan pada setiap siklus. Perbandingan antara pra siklus dengan siklus I menunjukan kenaikan 1,1 poin atau $0,8 \%$, siklus I dengan siklus II menunjukan kenaikan 0,6 poin atau $11 \%$, dan siklus II dengan siklus III menunjukan kenaikan 0,6 atau $11,8 \%$. Perbandingan ini menunjukan perubahan pengendalian diri peserta didik aspek kontrol kognitif setelah menerima konseling kelompok pendekatan PMRT, sehingga dapat dinyatakan bahwa konseling kelompok pendekatan PMRT memiliki kontribusi positif dalam meningkatkan pengendalian diri peserta didik aspek kontrol kognitif.

Perkembangan pengendalian diri peserta didik aspek mengontrol keputusan menunjukan kenaikan pada disiklus II dan siklus III. Perbandingan antara pra siklus dengan siklus I menunjukan penurunan sebesar $-1,6$ poin atau $0,4 \%$, namun siklus I dengan siklus II menunjukan kenaikan 0,1 poin atau $0,11 \%$, dan siklus II dengan siklus III menunjukan kenaikan 0,8 atau $0,06 \%$. Perbandingan ini menunjukan perubahan pengendalian diri peserta didik aspek kontrol kognitif setelah menerima layanan konseling kelompok pendekatan PMRT, sehingga dapat dinyatakan bahwa konseling kelompok pendekatan PMRT memiliki kontribusi positif dalam meningkatkan pengendalian diri peserta didik aspek mengontrol keputusan meskipun antara pra siklus dengan 
siklus I masih terjadi penurunan, namun siklus II dan siklus III memiliki perubahan yang positif terkait peningkatan pengendalian diri peserta didik aspek mengontrol keputusan.

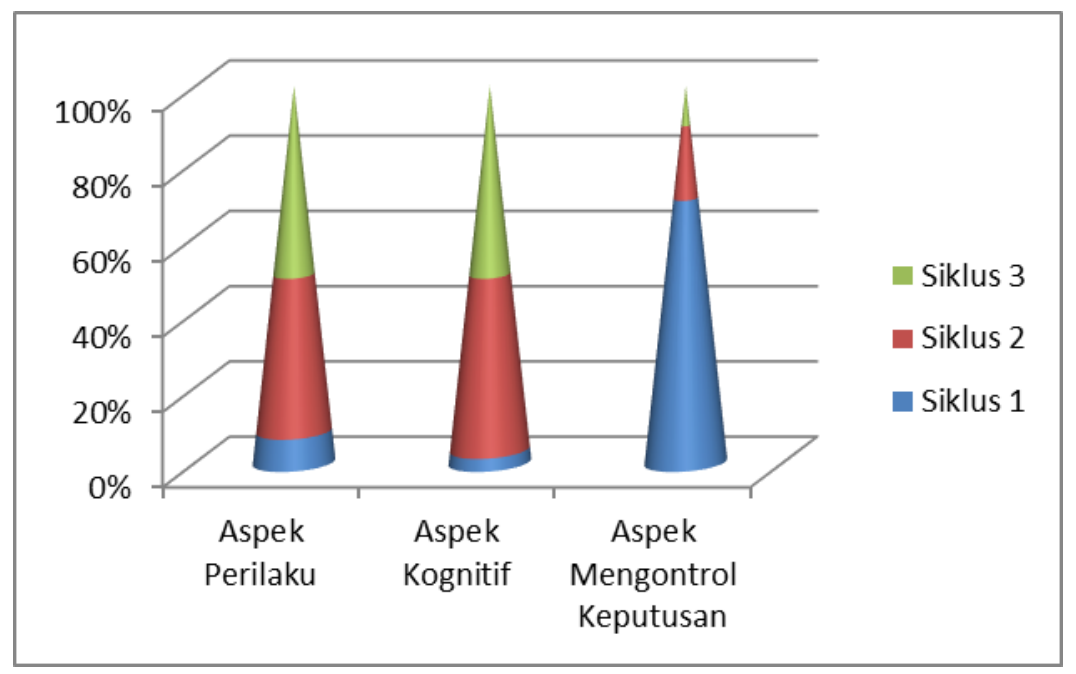

Grafik 2

Perkembangan Aspek-aspek Indikator Pengendalian Diri

Hasil pengamatan perkembangan pengendalian diri peserta didik menunjukan kenaikan pada setiap siklus. Perbandingan antara pra siklus dengan siklus I menunjukan kenaikan 10 poin atau $21 \%$, siklus I dengan siklus II menunjukan kenaikan 1,6 poin atau 34\%, dan siklus II dengan siklus III menunjukan kenaikan 4,5 atau 9,2\%. Perbandingan ini menunjukan perubahan pengendalian diri peserta didik setelah menerima konseling kelompok pendekatan PMRT, sehingga dapat dinyatakan bahwa konseling kelompok pendekatan PMRT memiliki kontribusi positif dalam meningkatkan pengendalian diri peserta didik.

Berdasarkan penilaian pengendalian diri pada siklus I, II, dan III terdapat 10 peserta didik yang tidak menampakkan perubahan pengendalian diri secara signifikan. Peserta didik ARN dimulai pada pra siklus sampai siklus ke-3 tetap dalam kondisi sedang, dan peserta didik AL, DEKA, FAR, IRI, RDP, SNF, SA, SK, dan WN memiliki perubahan yang awalnya pada kategori rendah di pra siklus memiliki perubahan pada siklus ke-2 dalam kategori sedang dan kondisi ini bertahan sampai pada siklus ke-3.

Memperhatikan indikator kinerja dalam penelitian tindakan bimbingan dan konseling ini, hasil penilaian pengendalian diri secara umum dari ketiga siklus telah mencapai indikator kinerja penelitian. Hal ini dibuktikan bahwa penghitungan rata-rata pengendalian diri secara umum menunjukan 76,4 poin atau $63,7 \%$ dan per indikator menunjukan 12,7 atau $63,5 \%$. Pencapaian indikator kinerja penelitian menunjukan bahwa tindakan konseling kelompok pendekatan PMRT efektif meningkatkan pengendalian diri peserta didik kelas X MIPA 3 SMA Negeri 2 Brebes tahun pelajaran 2018/2019.

\section{SIMPULAN}

Usaha meningkatkan pengendalian diri peserta didik kelas X MIPA 3 SMA Negeri 2 Brebes tahun pelajaran 2018/2019 melalui layanan konseling kelompok pendekatan PMRT (progresive muscle relaxation training) sebagai upaya perbaikan kualitas layanan konseling kelompok yang dilakukan oleh guru bimbingan dan konseling (peneliti) untuk memperoleh dampak yang positif terkait perkembangan pengendalian diri peserta didik, hal ini dapat ditelusuri hasil refleksi pada setiap siklus pelaksanaan tindakan bimbingan dan konseling.

Refleksi pada siklus pertama secara umum, proses layanan konseling kelompok pendekatan PMRT berjalan dengan baik meskipun pada awal kegiatan cenderung masih gugup, kebingungan mementukan materi, dan penerima layanan kurang memberikan apresiasi yang baik. Keadaan ini 
dapat direduksi melalui pendampingan guru bimbingan dan konseling (peneliti) agar konseli (penerima layanan) tetap dalam keadaan nyaman dan termotivasi dalam mengikuti layanan.

Refleksi siklus kedua secara umum, proses layanan konseling kelompok pendekatan PMRT berjalan dengan baik dan tampak terjadi perubahan yang lebih baik dari siklus pertama. Kecenderungan gugup yang tidak nampak, hal ini dipengaruhi oleh pengalaman pada siklus 1 dan dijadikan perhatian untuk melakukan perubahan pelaksanaan layanan konseling kelompok pendekatan PMRT yang lebih baik, materi lebih terkuasai, dan penerima layanan memberikan apresiasi yang baik. Keadaan ini merupakan peningkatan keberhasilan layanan konseling kelompok pendekatan PMRT dibandingkan pada siklus pertama, namun pendampingan guru bimbingan dan konseling (peneliti) tetap dilakukan agar konseli (penerima layanan) tetap dalam keadaan nyaman dan termotivasi dalam mengikuti layanan.

Refleksi siklus ketiga secara umum, proses layanan layanan konseling kelompok pendekatan PMRT berjalan dengan baik dan tampak terjadi perubahan yang lebih baik dari siklus pertama dan kedua. Kecenderungan peserta gugup tidak nampak, hal ini dipengaruhi oleh pengalaman siklus pertama dijadikan perhatian untuk melakukan perubahan pelaksanaan layanan konseling kelompok pendekatan PMRT yang lebih baik, materi lebih terkuasai, dan penerima layanan memberikan apresiasi yang baik. Keadaan ini merupakan peningkatan keberhasilan layanan konseling kelompok pendekatan PMRT dibandingkan pada siklus pertama dan kedua, namun pendampingan guru bimbingan dan konseling (peneliti) tetap dilakukan agar konseli (penerima layanan) tetap dalam keadaan nyaman dan termotivasi dalam mengikuti layanan.

Hasil refleksi pada setiap siklus menunjukan perubahan konseli (anggota) atau konseli (penerima layanan). Perubahan konseli mencakup kondisi yang lebih mantap, menguasai materi dan komunikasi yang dapat diterima. Bagi konseli (penerima layanan) yang awalnya kurang memiliki apresiasi yang baik berubah pada siklus kedua dan ketiga lebih mengarah pada kondisi perubahan apresiasi yang baik oleh konseli (penerima layanan).

\section{SARAN}

Berdasarkan hasil simpulan di atas, saran atau rekomendasi penelitian diproyeksikan pada guru bimbingan dan konseling untuk dapat menggunakan pendekatan layanan konseling kelompok pendekatan PMRT khusus untuk meningkatkan pengendalian diri peserta didik.

\section{DAFTAR PUSTAKA}

Erford, B.T. 2016. 40 Teknik yang Harus Diketahui Setiap Konselor. Edisi Kedua. Pustaka Pelajar: Yogyakarta.

Fadillah, Galih Fajar (2013). Upaya Meningkatkan Pengendalian Diri Penerima Manfaat melalui Layanan Bimbingan Kelompok di Balai Rehabilitasi Mandiri Semarang. Skiripsi, dipublikasikan. Universitas Negeri Semarang.

Ghufron, M.N. \& Risnawati, R. 2011. Teori-teori Psikologi. Yogyakarta: Arr-Ruzz Media

Handayani, Yulia (2017). Pengaruh Konseling Kelompok dengan Teknik Relaksasi untuk Membantu Penerimaan Diri pada Penyandang Tuna Daksa di Balai Besar Rehabilitasi Sosial Bina Daksa (BBRSBD) Prof. Dr. Soeharso Surakarta. Skripsi, dipublikasikan. IAIN Surakarta.

Hermanto. (2009). Pengertian Kontrol Diri. http://kasturi82.blogspot.com. (akses 2018/10/04).

Nurihsan, A. J. 2012. Strategi Layanan Bimbingan \& Konseling. Refika Aditama: Bandung.

Safaria, T. 2004. Terapi Kognitif-Perilaku untuk Anak. Yogyakarta: Graha Ilmu 
Safitri, Erna (2019). Efektifitas Progreesive Muscle Relaxation dalam Mengatasi Stres Belajar pada Peserta Didik di MA Al- Hikmah Bandar Lampung. Skirpsi, Dipublikasikan. Universitas Islam Raden Intan Lampung.

Sudjana. 1996. Teknik Analisis Regresi dan Korelasi. Bandung: Tarsito.

Sugiyono. 2006. Statistik untuk Penelitian. Bandung: Alfabeta. 